\title{
LARVICIDAL ACTIVITY OF ESSENTIAL OIL OF GLIRICIDIA SEPIUM LEAF
}

\author{
UMADEVI A. , ABDUL JALEEL \\ Department of Pharmacognosy, Moulana College of Pharmacy, Malappuram, Kerala, India \\ Email: umanair40@gmail.com
}

Received: 14 Aug 2019, Revised and Accepted: 24 Oct 2019

\section{ABSTRACT}

Objective: This study focus at the larvicidal activity of essential oil of Gliricidia sepium leaf

Methods: Pharmacological evaluation of leaf was carried out for larvicidal activity. Household mosquitoes of fourth instar larvae were used for the study. The study was carried out for 5 different concentrations for aqueous extract.

Results: The aqueous extract shown dose-dependent activity with the maximum larvicidal potential was seen with leaf of essential oil (250 mg/ml).

Conclusion: The study is designed to evaluate the larvicidal activity of essential oil of leaf of $G$. sepium. The relationship between the chemical composition and biological activity of essential oil of G. sepium is confirmed by lethal effect.

Keywords: Gliricidia sepium leaf, Larvicidal activity, Mosquitoes

(c) 2020 The Authors. Published by Innovare Academic Sciences Pvt Ltd. This is an open access article under the CC BY license (http://creativecommons.org/licenses/by/4.0/)

DOI: http://dx.doi.org/10.22159/ijcpr.2020v12i1.36827. Journal homepage: https://innovareacademics.in/journals/index.php/ijcpr

\section{INTRODUCTION}

Plants can be alternative sources of effective and safe mosquito control agents. In the past several decades, a number of synthetic chemical insecticides have been developed and effectively used to control mosquitoes. Unfortunately, the application of such chemical insecticides has resulted in long term harmful effects on the environment and non-target organism including human beings. In addition, the management of these disease vectors using synthetic insecticides has failed in part due to their efficiency in attaining physiological resistance. Herbal plants or botanical medicines have been used traditionally by herbalist worldwide for the prevention.

Plants are rich source of bioactive chemical compounds with insecticidal properties. The activity of crude plant extracts is often attributed to the complex mixture of active compounds. Crude extracts of leaves or bark of these plants have been tested earlier by several investigators. The plant Gliricidia sepium (fabaceae) traditionally claimed to possess larvicidal activity [1-3]. Therefore, the potential for exploiting these essential oils for vector control, can be taken into account. Plant oils have been used for centuries as fumigants and topical formulations applied to exposed skin. A wide variety of plant oils have been used as toxicants with ovicidal, larvicidal, pupicidal and adulticidal activities to sub-lethal effects including repellent action. Therefore, the present work was carried out to study the larvicidal activity of essential oil of Gliricidia sepium leaf [4-5].

\section{MATERIALS AND METHODS}

\section{Plant material}

Gliricidia sepium leaves were collected from Kasaragod district, Kerala, India. The sample drug has been identified and authenticated from the Department of Botany, Govt College Kasaragod.

\section{Preparation of extract}

For the isolation of essential oil from the leaf, fresh leaves are subjected to hydrodistillation at atmospheric pressure for $3 \mathrm{~h}$ using Clevenger type apparatus. The distilled oil was collected and dried over anhydrous sodium sulphate [6-7].

\section{Larvicidal activity}

\section{Mosquito culture}

Mosquitoes were collected from stagnant water areas of different places of Kerala. To start the colony and larvae were kept in plastic and various pot containing tap water. They were maintained and all the experiments were carried out at $27 \pm 2{ }^{\circ} \mathrm{C}$ and 75-85 percent relative humidity under14:10 h light and dark cycles. Larvae were fed a diet of dog or biscuits and algae collected from ponds [8].

\section{Larvicidal assay}

Essential oils of G. sepium leaf dissolved in dimethylsulfoxide (DMSO) (1\% stock solution of essential oil in DMSO) were placed in $500 \mathrm{ml}$ beakers and added to water that contained 50 larvae (fourth instar). With each experiment, a set of controls using DMSO was also run for comparison. Mortality was recorded after $24 \mathrm{~h}$ and again after $48 \mathrm{~h}$ of exposure, during which no nutritional supplement was added. The number of dead larvae in each beaker was counted after $24 \mathrm{~h}$ of contact at room temperature. The number of dead larvae at $0,1,2,3,4,6,12,24 \mathrm{~h}$ was recorded and the percentage mortality was calculated. The study was performed in triplicate and the average of the study is taken. The larvae were considered dead if they were immobile and unable to reach the water surface. The experiments were carried out at $25 \pm 2{ }^{\circ} \mathrm{C}$. Dimethylsulfoxide was used as a control [9-10].

\section{RESULTS AND DISCUSSION}

In the present study, an attempt has been made to untap one of the fabaceae family that is Gliricidia sepium for its larvicidal potential. In this study the efficacy of the volatile oil from the leaves was evaluated against fourth Instar larvae of Aedes aegypti at various concentrations of $10,25,50,100,250 \mathrm{mg} / \mathrm{ml}$. The results were shown in table 1 . The essential oil was evaluated at $0,1^{\text {st }}, 2^{\text {nd }}$. $3 \mathrm{rd}, 4$ th, 6th, 12th and 24th hour. The evaluation clearly shows volatile oil exhibits larvicidal property dose-dependently. A dose-dependent effect on mortality was recorded with increasing concentrations of essential oil and compounds increasing the mortality of the larvae. Larvicidal bioassays revealed that $24 \mathrm{~h}$ mortality rate of the whole essential oil was $250 \mathrm{mg} / \mathrm{ml}$.

Plant-derived toxicants are valuable source of potential insecticides. They play a major role in mosquito control programs in near future. So, there is always a tremendous need in plant insecticides throughout the globe. These plant-derived insecticides are effective against specific target insects, less expensive, easily biodegradable and to non-toxic products. 
Table 1: Results of an evaluation of the larvicidal potential of essential oil of Gliricidia sepium leaf

\begin{tabular}{|c|c|c|c|c|c|c|c|c|c|}
\hline \multirow[t]{2}{*}{ Treatment concentration $(\mathrm{mg} / \mathrm{ml})$} & & \multicolumn{8}{|c|}{ Percentage mortality } \\
\hline & & $\mathbf{O} \mathbf{h}$ & $1^{\text {st }} \mathrm{h}$ & $2^{\text {nd }} h$ & $3^{\text {rd } h}$ & $4^{\text {th }} \mathbf{h}$ & $6^{\text {th }} h$ & $12^{\text {th }} \mathrm{h}$ & $24^{\text {th }}$ h \\
\hline \multirow[t]{6}{*}{ Control essential oil of $G$. sepium } & & 00 & 00 & 00 & 00 & 00 & 00 & 00 & 00 \\
\hline & 10 & 00 & 00 & 00 & 00 & 00 & 00 & 00 & 1 \\
\hline & 25 & 00 & 00 & 00 & 00 & 3 & 5 & 7 & 9 \\
\hline & 50 & 00 & 00 & 00 & 5 & 9 & 12 & 15 & 18 \\
\hline & 100 & 00 & 3 & 10 & 13 & 15 & 20 & 22 & 30 \\
\hline & 250 & 5 & 13 & 15 & 20 & 28 & 35 & 40 & 45 \\
\hline
\end{tabular}

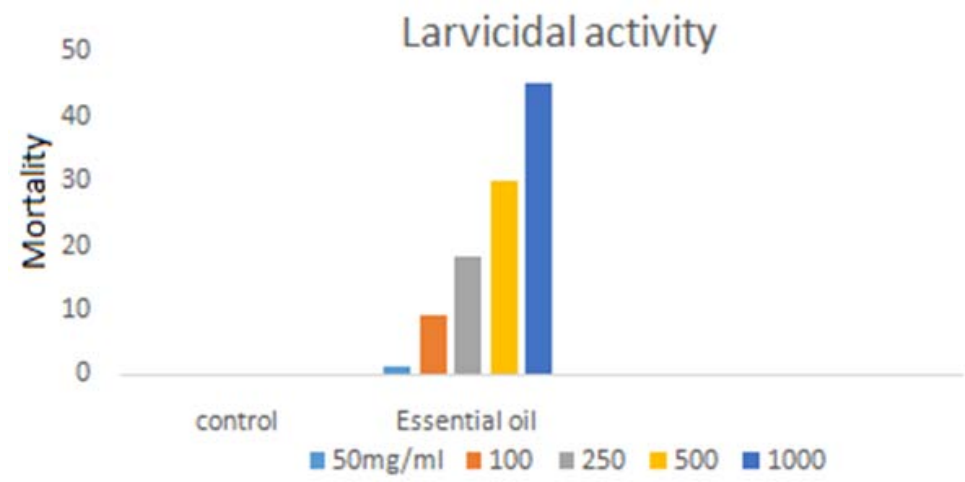

Fig. 1: larvicidal activity of essential oil of Gliricidia sepium

\section{CONCLUSION}

The present study reveals that, larvicidal activity of volatile oil from Gliricidia sepium leaf by using mosquito larvae was confirmed. Further works are being carried out to isolate and identify the active principle involved in the larvicidal activity of plant extracts.

\section{ACKNOWLEDGMENT}

We are very thankful to respected the principal and management of Moulana College of pharmacy, Kerala for their support.

\section{FUNDING}

Nil

\section{AUTHORS CONTRIBUTIONS}

All the author has contributed equally.

\section{CONFLICT OF INTERESTS}

Declared none

\section{REFERENCES}

1. Jayakumar M, Arivoli S, Raveen R, Tennyson S. Larvicidal and pupicidal efficacy of plant oils against culex quinquefasciatus say 1823 (Diptera: Culicidae). J Entomol Zool Studies 2016; 4:449-56.

2. Shad A, Andrew J. A study on the larvicidal activity of some medicinal plant extracts from Western Uttar Pradesh India, against the filarial vector, culex quinquefasciatus say. Int J Curr Microbiol Appl Sci 2013;2:423-32.
3. Kumar KP, Naik VS, Chandra VB, Lavanya R, Kumar KN, Bhagyasree $\mathrm{V}$, et al. Evaluation of in vitro and in vivo antiinflammatory activity of aqueous extract of Gliricidia sepium flowers in rats. Int J Pharmacogn Phytochem Res 2014;6:477-81.

4. Akharaiyi FC, Boboye B, Adetuyi FC. Antibacterial, phytochemical and antioxidant activities of the leaf extracts of gliricidia sepium and spathodea campanulate. World Appl Sci J 2012;16:523-30.

5. Chen XB, Liu XC, Zhou L, Liu ZL. Essential oil composition and larvicidal activity of Clinopodium gracile (Benth) matsum (Labiatae) aerial parts against the aedes albopictus mosquito. Trop J Pharm Res 2013;12:799-804.

6. Dinde AV, Lokhande PB, Mujawar HA. Essential oil extraction, characterization and anti-microbial study of Cythocline purpurea from konkan region. J Pharm Res 2017;11:424-9.

7. Chaverri C, Ciccio JF. Leaf and flower essential oil compositions of Gliricidia sepium (Fabaceae) from costa rica. Am J Essen Oils Nat Prod 2015;2:18-23.

8. Onyido AE, Ozumba NA, Ezike VI, Ikpeze OO, Nwankwo AC. New method of rearing and maintenance of mosquito colony in the laboratory. Afr J Biosci 2009;2:16-9.

9. Sandhya C, Rani JM. Larvicidal activity of crude plant extract against fourth instar larvae of anopheles subpictus and Culex quinquefasiatus mosquitoes. Int J Sci Res 2017;6:1635-7.

10. Santos HS, Bandeira PN, Lemos TLG, Santiago GMP. Chemical composition and larvicidal activity against aedes aegypti L. (Diptera: Culicidae) of essential oils from leaves, stalks and roots of the croton nepetaefolius baill (Euphorbiaceae). Int J Mosq Res 2017;4:19-22. 